\title{
I Will Not Forget the Land Where I Was Born-The Educational Legacy of Oliveira Lopes Brothers
}

\author{
Cláudia Pinto Ribeiro \\ University of Oporto, Portugal
}

\author{
Luís Alberto Alves \\ University of Oporto, Portugal
}

\begin{abstract}
The tendency to participate with solidarity in the religious and assistance initiatives is a trademark of the Portuguese who returned from Brazil. The major novelty in the second half of the nineteenth century is the conduction of large sums of money towards education, in a framework of philanthropy that was unusual. This inclusion of education in the field of charity was in the concerns of politicians and intellectuals of the time who argued that "only by educating people, nations can achieve its independence, wealth and freedom (...)". Inserted in this context we can find examples that deserve, by their paradigmatic profile, a more detailed attention. After making fortune, Oliveira Lopes and his brother tried to solve problems that seemed without solution in their homeland. This example assumes a synthetizing nature for several reasons. Firstly, because it portraits the typical Brazilian of the end of the nineteenth century that saw education as a fundamental tool to approach Portugal to the international standards. Secondly, because with the well-being of his fellow countrymen and the "notoriety of his hometown" he can diminish the pain of the "abandonment in search of wealth". Thirdly, because his return introduced a new sense and a new rhythm in searching solutions for eternal problems in the field of religion, assistance or education. Finally because, even though they are the minority of Brazilians that achieved fortune, they put their wealth in the service of the country that made them leave in order to try to stop the flux of emigrants.
\end{abstract}

Keywords: school museum, history of education, material culture

\section{From Colony to Independent State}

Brazil was fertile ground for the most far-fetched imageries of $19^{\text {th }}$-century and early $20^{\text {th }}$-century Portugal and, at the same time, the most present reference in various spheres of national life in that period. Those indelible marks are owed not only to what the Brazilian space continued to represent for several aspects of Portuguese life, but essentially due to the creation of the character that left its mark on Portuguese social life - the Brazilian, that is, the Portuguese emigrant returning from Brazil.

The first marks of our modern times are inseparable from the Brazilian colonial reality, which at times (1807-1821) and given the presence of the king, takes on the role of metropolis. This unexpected prominence will drive Brazil towards a new identity which will allow it to break away from the colonial chains (1822), despite the Velhos do Restelo [the prophets of doom], in the form of constitutionalists, who took too long to realise the inevitability of the separation:

The Portuguese nation represents the union of all Portuguese of both hemispheres. Its territory forms the United Kingdom of Portugal, Brazil and the Algarve (...). ${ }^{1}$

\footnotetext{
${ }^{1} 1822$ Constitution (full text). Braga: Livraria Victor-Centro Cultural do Minho, 1954, p. 9 (Art 20).
} 
Once independence was recognised in 1825-after most European countries had already done so since 1822 - it was time to accept all the consequences of this "beginning of the absence" of a space that dragged us, in terms of history and because of its wealth, towards an inadvisable policy of transport. The clarity shown by Mouzinho da Silveira in the revolutionary legislation of 1832 would cause the shift from the cycle of conquests to that of productive activities:

The kingdom has lived for more than three centuries from the labour of slaves, but once these were gone, a new way of life had to be found, multiplying the values of work on one's own (...).

Only the ports of Brazil were open to all, and the relative monopoly ceased to existed, as did the wealth many Portuguese had acquired there to bring to Lisbon, Portugal descended even more into the abyss than it had risen during the glorious times (...).

Portugal cannot continue to be an independent nation without advancing its labour and industry (...). ${ }^{2}$

The fact we were able to unequivocally accept the need to regardour former colony from another perspective, combined with a relative political stability and with the need to focus on an effective settlement policy, would enable an evaluation of our ability to make the most of the country's potential. Disappointment soon took hold of the best expectations and the best scenarios defined for the required development. Although slow, demographic growth soon put pressure on and expelled population "surpluses". Civil governments soon saw an increasing number of candidate emigrants (legal) and our ports became filled with people eager for a place for adventure.

After having the Brazilian colony in its history, Portugal could have also saved some space for the Portuguese people who, on the other side of the Atlantic Ocean, hoped to find what avaricious mainland Portugal hid from them, cynically returning to it, and whenever possible in a generous way, what it denied them - the opportunity for a better life.

\section{From Being Portuguese to Being Brazilian}

Emigration to Brazil has been a constant phenomenon in our history, lasting until the 1960s as a priority destination and, at times, practically the only one. In this respect, as a destination, a facilitator of dreams impossible to achieve in mainland Portugal and as a relief valve of both demographic growth and of the absorption capacity of production facilities, the Brazilian space defined itself as a mandatory reference in our modern-day history. We only need to bear in mind the conditions endured during the sea voyages in the second half of the 19th century-_"...) poorly fed, harboured like animals in cramped, dirty, hot and smelly spaces, hiding in ship holds on their arrival in Rio de Janeiro, to avoid being caught by the consular authorities (...)"3_ to realise how important this rediscovery of Brazil was in the imagery and reality of some Portuguese families.

Thousands of Portuguese nationals found their way across the Atlantic in the second half of the 19th and early 20th centuries based on a reciprocity of interests, as the Brazilian economy needed capable hands to replace slavery, which, in the meantime, had been abolished ${ }^{4}$, and hoped to make the best of a work force

\footnotetext{
2 Sá, 1981, pp. 105-111.

3 Cruz, 1991, p. 188.

4 “(...) The former colony, that had based all its economy on slave labour, began on 4th September 1850, as approved by Imperial decree 584 which established the final regulations on the suppression of the slave trade, a long and difficult journey that would lead to the abolition of slavery on 13th May 1888 (Golden Law)(...)”. In Ibidem, p. 186.
} 
wasted by the "unrealised Portuguese industrialisation". The money sent by the emigrants guaranteed a fragile and delicate balance of the Portuguese finances; the investments made in mainland Portugal by some of the better off Brazilians in a way compensated the Diaspora and brought in a new type of social actors, repeatedly commented by numerous writers.

From Camilo Castelo Branco to Ferreira de Castro, including Júlio Dinis and Eça de Queirós, the figure of the Brazilian took on an identity that reproduces, as a whole, an accurate picture of its place in society and in the economy of that time. Whether the figure is Feliciano in "A Brasileira de Prazins", Manuel da Bouça in "Emigrantes", Eusébio Seabra in "A Morgadinha dos Canaviais", or José Urbano in the short story "Justiça de Sua Majestade", or "Mr. Bazílio de Brito" in "O Primo Basílio", they all reflect the different hopes in the outward journeys, the different meanings of the stays and, in particular, the different impacts of the homebound journeys.

The image of success or failure conveyed in the literature depicts the reality of Brazilian emigration at that time:

(...) One can say that of 100 individuals who emigrate, only 40 will return, 20 of which come back as poor as when they left and in poorer health, 15 have a little capital enough just to set up their industry in better conditions, or buy a property in their home towns, and 5 return with a sound fortune (...). 5

Recent studies comparing a large amount of other data, including analyses of passport applications and elements on the travels of some emigrants, point to about $40 \%$ and $60 \%$ return rates, reaffirming, on the one hand, the importance of those who return and abandoning the idea of a demographic "bleed-out" that only took into account the outward movement.

\section{The Return of the Brazilian}

The homebound journey is made between the ages of 40 and 50, depending on how lucky they are in Brazil, on the investment opportunities in Portugal, and on surrendering upon realising that prolonging the stay will not improve the situation. Besides the many travels to and from Brazil, particularly the successful businessmen linked mainly to commercial activity, the main purpose for those between the ages of 42 and 50 was to have a stable life in the much longed-for homeland.

The return was to be marked by an effort to be reintegrated, always seeking to be discreet and ashamed when the return is tarnished by failure, or grand and ostentatious when economic success marked his stay in the land of Vera Cruz. History will reserve a privileged place in particular for the successful Brazilian, on the basis of his new status.

Upon his return, the social and economic role played throughout the stay in Brazil, by regularly sending money to the family, becomes more intense and diversified. More intense because there is a clear desire to show himself (and show off) in the living space, which he modifies and creates with his foreign-like marks. More diversified because whereas he did not forget his origins while living across the Atlantic, it nevertheless opened new horizons as to how to multiply his savings or make a fortune.

For many of them, having assumed the clear purpose of going to Brazil to solve the problems that an impoverished primary sector had created due to troubled times, customs tariffs, or agricultural crises, to return

\footnotetext{
${ }^{5}$ Primeiro Inquérito Parlamentar sobre a Emigração Portugueza pela Commissão da Camara dos Senhores Deputados. Lisboa: Imprensa Nacional, 1873, p. 176.
} 
meant they would be able to pay their debts, improve their houses, or buy new land. For their daughters, it could mean having a dowry that would make them more eligible to marry, in a context where love would not be sufficient.

On a more capitalist note, better suited to the experiences that living in contact with other worlds had provided them, the banking institutions, the public limited companies, the trade, the industry, the hotel business and insurance were seen as profitable investments in which the Brazilians could invest all their experience and, especially, quickly multiply their fortunes. Banco Comercial do Porto, Mercantil Portuense, Banco União, Seguros Garantia, Mineração Perseverança, Carris do Porto, Companhia do Palácio de Cristal and the Grande Hotel do Porto are only a tiny show of what the presence of Brazilian money represented, especially in the northern part of the country where the overwhelming majority of those who sought the various Brazilian destinations lived, the possibility of taking fast steps towards industrial and financial capitalism ${ }^{6}$.

The contemporaries reaffirm the meaning of this Brazilian return:

(...) We have lately received from blessed Brazil fortunes and some active and enterprising men, who have reserved part of their lives to come and put it to their own use and that of their country. Before, it was only money that came. Those who brought it, they either came to Caldas, or then spent the winter in bed. Their lives were exhausted from work. They had nothing else to give. Today, the quick and easy communications have transformed everything. They absorb from America habits and work skills that are learned as a result of needs in places away from the family home. Some of the important houses in Lisbon and Porto, as well as some of the modern companies are governed by individuals who started their careers in Brazil (...). ${ }^{7}$.

The marks of the presence of this well-off Brazilian extend far beyond an obsessive and exclusive concern with work. His religious conscious and love for his village are shown in the many ways in which he shows his success. Whether it is Eusébio Seabra, who "began some repair works in the parish church and offered new garments for all the saints in the altar, and had a church bell repaired because it had been making a cracked sound for twelve years" Senhora de La Salette", they are all quite enthusiastic about being useful "to the place where they were born" and to the their fellow-villagers who stayed behind.

It will be, however, in education, in particular primary education, where we will be able to better assess the new mentality brought by the Brazilians and the philanthropic sense they like to give to their wealth.

\section{Education in the Horizons of Solidarity of the Brazilian}

The tendency to participate in a spirit of solidarity in religious and health care initiatives is the hallmark of the Portuguese man returning from Brazil. For a long time, the charity institutions or the village priests played the role of interlocutors between the kindness of the emigrants and the needs of the places in which they lived. This attitude represents a visible appreciation for their success, but also meant continuing the way in which these generous offerings were used.

The great novelty which we will see from the second half of the 19th century on is that significant amounts of money are channelled into education, in a framework of philanthropy that the country was not used to. To include education in the charitable area was one of the concerns of politicians and intellectuals at that

\footnotetext{
${ }^{6}$ Mónica, 1987, pp. 819-863.

7 Alves, 1994, p. 308.

${ }^{8}$ Dinis, 1982, pp. 163-164.

9 Castro, 1977, p. 44.
} 
time, who held that "(...) it is only through the education of the common people that the nations will achieve their independence, richness and freedom ... because education is, in itself, a virtual progress in any kind of endeavour (...)"10. This commitment sprang from the concern with an illiteracy rate of $75 \% 11$ in 1910, which hindered a real and consistent economic growth and a political clarification that would necessarily have to provide more access to information and would have to reduce (or if possible abolish) the influence of political landlords, curiously an area of intervention dear to many Brazilians, to rise to a new social status (together with nobilisation).

The number of examples began to increase: in Santo Tirso, the Count of S. Bento founded an Agricultural Home, two schools, the Misericórdia Hospital, the Tirsense Club, and the Santo Tirso Factory; in Leça da Palmeira, Maria Francisca dos Santos Araújo built a school for girls with the inheritance she received from her brother José Pinto de Sousa; in Maia, the Viscount of Barreiros used part of his fortune in education, improving old schools and building new ones; in Vila do Conde, José da Silva Carneiro invested in a school for both boys and girls; also in Vila do Conde, the Viscount of Santa Marinha wished to donate part of his income to improve the education level of the local population. At the same time as these examples of individual financial availability, others existed but less personal, but no less important, for example, the Liga Propulsora da Instrução in Portugal [Education League], established by the S. Paulo Portuguese City Council, who set aside in 1930, 600 contos [thousand escudos] for the construction of "hygienic and modern school buildings in the regions more remote from the main centres and less privileged in terms of official education". Following these intentions, five new schools were built in Freixo Numão and Vilar Formoso (Guarda); Camarneira and Avelãs de Caminho (Coimbra) and Rio de Moinhos (Viseu).12

Although different investments were made in the various levels of education, primary education was the primary focus of generosity, thus addressing the support that the political power wished to give to a sector known for its shortcomings: "the lack of properly qualified teachers, the lack of school facilities, the lack of schools for girls"13.

Within this context of political and national concern, and of emphasis on areas targeted by the Brazilian generosity, we will find examples that due to their pragmatic nature deserve a more detailed study. We have chosen the inevitable Joaquim Ferreira dos Santos, but also the Oliveira Lopes brothers and Domingos Joaquim da Silva.

(...) I am convinced that public education is essential for the good of society, so I want my executors to order the building and furnishing of one hundred and twenty houses to be used as primary schools for both genders, in the municipal seats, consisting of one same plan, with accommodation for the teacher, each house and furniture costing no more than $1,200 \$ 000$ reis; when each house is ready, it will be given to the board of the parish in which the school is built; there will be no more than two houses in each municipal seat, and they may choose the location as they see fit (...). ${ }^{14}$

This legacy that, according to D. António da Costa, should be "written in golden letters"15, represents a significant milestone in Portuguese primary education at various levels.

Firstly, because it is a provocation against the political power, which had allocated from the 1866 budget

\footnotetext{
${ }^{10}$ Horta, 1881, pp. 44-45.

11 Reis, 1993, p. 16.

12 Rocha-Trindade, 1986, p. 153.

13 Gomes, 1985, pp. 127-180.

14 Ribeiro, 1884, pp. 5-6.

15 Costa, 1900, p. 197.
} 
the ridiculous amount of $10.000 \$ 000$ reis to the "construction plan for primary education"16, considered a priority area of investment, in particular in the election programmes of the various parties. Additionally, one could infer the foolishness of never having established a Ministry of Education until then, which only materialised sporadically in 1870 .

Second, because it will force this very political power to define and assume itself and, obviously, to provide appropriate legislation in a sector where the occasional measures, lacking continuity and especially identity, were embodied as customary. The legislation published already on 27th June and 20th July 1866, reveals the embarrassment that the legacy had caused, and the need called attention to the value of education and instruction:

(...) In terms of education and public instruction, the loss of one day may be the moral loss of many members of society, for which it has the duty to watch over, and is responsible for helping diligently in the successive periods of life.

(...) it is essential to draw attention to the civil governors and education commissioners about education and instruction affairs that are entrusted to their care and diligence (...). ${ }^{17}$

(...) The expropriation of houses or land needed for the construction of buildings and related facilities are considered of public utility, intended for the establishment of public primary schools. The expropriation processes for this purpose are free of charge even when a dispute is involved.

(...) The parish boards may lease or sell in a public auction their own assets or commonage land and common paths, and use the proceedings to buy, build, rebuild or repair primary school buildings to be established in their parishes.

(...)The city councils are authorised to contract, with the executors of the late Count of Ferreira, the construction of buildings and the provision of furniture for the primary school buildings, commissioned pursuant to the testamentary provisions of the Count (...). ${ }^{18}$

This transcript shows, on the one hand, the timeless meaning of the ideas that came up at each election time, but were always put aside once the party came to power, and on the other hand the importance of a legacy such as the one of Count of Ferreira for removing bureaucracy, which was always an excuse when decisions had to be made (in the case of Válega-Ovar, we will see that it was all just empty words). In fact, we just have to read the answers given by various city councils in 1875 to understand the reach of such bureaucracy ${ }^{19}$.

\footnotetext{
16 Bárbara, 1979, p. 57.

17 Colecção Oficial da Legislação Portuguesa - Ano de 1866. Lisboa: Imprensa Nacional, 1867, p. 320 (Preamble to the Ordinance of 20th July 1866).

${ }^{18}$ Ibidem, pp. 268-269 (Charter of 27th June 1866).

19 When the mayor of Guimarães in 1875 asked the other city councils (26 in total) how they were using the legacy of Count of Ferreira, he sent a small questionnaire with the following requests for information: date on which the executers offered the subsidy of 1,200\$000 reis; date when this subsidy was accepted; date on which the executers acknowledged the receipt of the contract; date on which the city council came into the possession of the land; starting date of construction; opening date of school; date when the subsidy was paid to the city council; doubts between the city council and the executers. From the answers given by some of the city councils, it is clear that the offers takes place between 22nd September 1866 (Caminha) and 14th January 1867 (Vila do Conde, Esposende and Gondomar), and they were accepted between October 1866 and 27th April 1870 (Póvoa de Varzim). Of the 17 city councils that answered, 5 did not accept or gave up the subsidy (Santo Tirso, Vila Nova de Gaia, Valença, Vieira do Minho and Barcelos). In 1875, date on which this private questionnaire was sent by the mayor of Guimarães, 10 city councils had already opened the new schools. According to the correspondence exchanged, it is clear that some places found it difficult to acquire land, and especially to find sources of income to cover the costs higher than the subsidy received. These answers essentially affirm the inability to meet the requirements of the 20th July 1866 law: “(...) The city councils or parish boards that want the subsidy (...) are required to provide the building and land plan, which should not be less than 600 square meters in addition to the area taken up by the building; the budget for the project; a copy of the overall or supplementary budget duly approved, with an amount of no less than $\$ 400000$ reis set aside for the construction of the desired school (...)." These
} 
From another perspective, the legacy addresses, at the same time, five of the most important problems in primary education: it underpins a lasting investment by supporting the construction of buildings; it strives to solve the housing situation for teachers, reducing travels to more distant areas from city centres; it addresses on the same level the need for education for both sexes; it envisions the school in global terms, attaching particular importance to the appropriate furniture 20 ; it gives the local power the responsibility for conservation, by handing the school over to the parish board, adopting a clear position regarding the discussion on centralisation or decentralisation of educational initiatives.

These aspects, together with a concern with architectural uniformity have allowed us to identify, even today, the "Conde Ferreira schools" that have survived our neglect for heritage, will also make them examples of involvement in Portuguese instruction that other Brazilians will use to also leave the mark of their solidarity with education in a country they have never forgotten, and which they have always wanted to bring closer to a greater civilisation.

The example of the Count of Ferreira will serve to awaken the benefactor minds of those who had been blessed by success. We would like to emphasise another example: the Oliveira Lopes Schools in Válega, Ovar.

The life story of one of the benefactors - José de Oliveira Lopes-summarises many of the examples that we have referred above:

(...) One day, after having lived long enough to love him, where he was born, José Lopes travelled to the lands of Santa Cruz and stayed there for many years, working and cherishing the golden dream of one day becoming useful to his fellow countrymen and his village. When he returned, he had a great fortune. That was a happy day, because the feelings of longing he had for his homeland and village, without that delicious sting, had transformed into a quiet love of possession, an active, laborious, communicative and benefactor love. Since then, plenty of droplets have fallen from that richness, in the form of rainfall of prosperity and joy, on the land where he was born (...). ${ }^{21}$

Having made a fortune away from the place where he was born, this Brazilian and his brother turned their attention to solving, precisely in this place, the problems that seemed insurmountable. The primary school teacher of Válega, Father Francisco Marques da Silva, had been appointed in 1864. In that same year, the search began for a worthy place for both the teacher and the students. More than 40 years elapsed dedicated to poor adaptations of old buildings, expropriations of land capable of accommodating the school, requests for subsidies by the Parish Board, and discussions involving the plan! When "at the (Board) meeting on 19th January 1908 (the brothers José and Manuel José Oliveira Lopes) submitted a request to build a house for the primary school in the Souto square, to be offered to the government... this patriotic and generous gesture was welcomed, as one would expect, with much enthusiasm, and the works soon began"22.

In early October 1910, before the re-establishment of the Republic, the following was said about the conclusion of works:

obligations coincided with another burden put on the consulted city councils for the acquisition of land for building the public cemeteries. Information collected in ARQUIVO MUNICIPAL DE GUIMARÃES, Relação das Camaras a quem se pediram informações sobre o subsídio legado pelo Conde de Ferreira. 1875.

20 The government is forced to legislate for the first time on the matter, standardising "the capacity and overall conditions of the building, exposure and lighting, ventilation, temperature, furniture and qualifications of teachers" (instructions contained in the Law of 20th July 1866).

${ }^{21}$ Almanaque d'Ovar para 1914. (S.1.), (s/data), pp. 78-79.

22 Oliveira, 1981, pp. 176-179. 
(...) The building is majestic, elegant, airy, situated in the most central place and in the largest square in the parish; the halls are enormous, but not disproportionate; the houses of the male teacher and female teacher, modern, forming a harmonious arrangement with the schools, are spacious, comfortable and well distributed. The school materials are first class, the mahogany furniture rivals with that of the best schools in Lisbon and Porto.

These schools were officially opened [for girls and boys] after works were completed, on 2nd October 1910 (...). ${ }^{23}$

Although it was inaugurated with pomp and "a pigeon shooting tournament" before the re-establishment of the Republic, the list of distinguished guests was a reflection of the sympathy José de Oliveira Lopes had for the republican ideals. In fact, from among the guests was António Valente de Almeida, president of the Municipal Republican Committee of Ovar, and representatives of the republican municipal and parish committees of Ovar and Válega. As was the practice, the inauguration was also attended by the Civil District Governor, A. Cardoso, the Government's representative, MP Egas Moniz, the Mayor of the City Council of Ovar, Joaquim Soares Pinto, the vice-school inspector, José de Castro Sequeira Vidal... and many anonymous people who wanted to witness that solemn event in their town.

The ceremony, followed by a banquet with the menu written in French (as dictated by etiquette), was in the newspapers the next day (Jornal de Notícias, O Primeiro de Janeiro, Comércio do Porto, Pátria), who praised the commendable work of these returned emigrant Brazilians.

The years that followed have sunk into oblivion. We know that in 1953 a school canteen was opened, next to the school building, also paid by one of the family's heirs, a nephew of José and Manuel José-Manuel Alves de Oliveira - and by António Maria Augusto da Silva. The role of this facility was essential to the local people: it gave them food, warmth, and allowed young girls to acquire practical knowledge of housekeeping. ${ }^{24}$

In the 1980s, the building was rehabilitated, leaving only the original external load-bearing walls. It was also in this decade that the museum-hall was built, commissioned by Joaquim de Almeida Pinho, a former teacher at the school,who collected and organised the collections. Indeed,

With the ideas then in vogue for improving the conditions, the school materials began to be replaced. When he realised that the school materials would be lost forever, that decades of history of education would be lost, unique items, irreplaceable documents, the teacher was overcome by a sort of illness, and practically alone, because his fellow colleagues at the school did not believe much in the project, set to work vigorously, surmounting every difficulty, to gradually store, preserve, and beg for support. He managed to recover and show the materials which today are admired and recognised by those interested in education issues. ${ }^{25}$

Once again, a descendant of the Oliveira Lopes family decided to support this initiative. With the help of the nephew José Pereira Herdeiromany of the original items of this school space were recovered. In this sense, one of the aspects that made this Museum unique is the fact that its collection is not the result of the collection of items from all over the council or even from beyond, but it consists of the original collection purchased by the founding benefactors. This amounts to saying that when we look at the classroom showcased at the museum, carefully reconstructed based on the information provided by period photographs, we know that rigour cuts across decades and finds in the original furniture the possibility of making a journey back in time.

The museum contains the following:

\footnotetext{
23 Ibidem, p. 179.

24 Pinho, 2010, p. 21.

25 Ibidem, p. 10.
} 
- Desks, cupboards, display cases and mahogany chairs (probably imported from Brazil);

- Mahogany chairs with a "two-screw mechanism under the seat to allow the chair to be lifted or lowered depending on the student's height" (according to the ergonomic studies that determined the healthy posture of students); ${ }^{26}$

- World globes by Forest, the Portuguese Chart in relief by Victória Pereira, dated from 1912, the political planisphere from the early $20^{\text {th }}$ century with the states, cities, colonies and roadways, the general map of America dated from1905;

- Painting of the History of Portugal by Carlos Franco and João Soares, with illustrations by Roque Gameiro and Alberto Sousa;

- Individual pictures (300 items) on natural sciences, geology, physics, arithmetic, Portuguese language...

If we look at, for example, the picture on "Lessons on Things - Madeira Island and its fruits", maps of cereals, medicinal plants, plant dyes, of products used in the industry, such as linen, hemp, cotton, silk; If we look at the picture with the Earth's History or others with the history of the production of iron, steel, copper, paper, glass, we have the image of the great book of Nature and human toil. We can also see the remarkable and unusual set of pictures on Physics (...) and realise that the Republic was interested in instilling in children respect and love for Nature (...).

The collection also includes metric and geometric boxes (...), the abacus, a type of mechanical counting system that helps to understand mathematical calculations (...), the reading book Cartilha Maternal de João de Deus (...). ${ }^{27}$

- Textbooks used at different times, since the monarchy to the New State period;

- Dictionaries such as those by José Roquete, published in Paris in 1856;

- Various documents related to the school administration, such as registration and enrolment books, exercise books, students' exams, etc.;

In October 1998, an agreement was signed between the Association of Former Students of the Oliveira Lopes School and the City Council, making the museum official. At the same time, 1st cycle classes continued to be taught for the children of the parish of Ovar. With the revamping of the school complexes, the drop in the number of students, the degradation of facilities and the construction of a school facility more suited to the learning activities (in Regedoura), the Oliveira Lopes School closed its academic activities, but strongly contested by the local population and forcing the involvement of certain entities (2014). The School Museum continued its activities, trying to ignore the surrounding controversies. Its activities include: a) visits by school children from all over the country, guided by the technical staff of the School Museum, who explain how the school first began, provide bibliographical data on its benefactors, the daily life of a school in the early 20th century, experiences and memories, the origins of the Museum and its operation; b) partnerships with the schools in the council network and from other regions, and also with shops, holding photograph exhibitions and showcasing items from the museum collection, in order to publicise the contents of the School Museum among the school audience and the public in general; c) collaboration with commemorative entities (National Committee for the Commemorations of the 100th Anniversary of the Republic, 2009-2010) as part of the national celebrations.

In November 2011, a musealisation proposal was made for an application to the QREN funds, entitled "Proposta de musealização da Escola Oliveira Lopes - Memória Justificativa", in a joint effort between the City Council of Ovar and the Department of Culture; of the Association of Former Students of the Oliveira Lopes

\footnotetext{
${ }^{26}$ Ibidem, p. 13.

27 Rodrigues, 2002, p. 14.
} 
School, and with the scientific and executive coordination of João Borges, Alice Semedo and Célia Machado.

The fruits of this initiative materialised a couple of years later. In fact, in early September 2015, the City Council of Ovar has indicated its intention to requalify the building of the Oliveira Lopes School. "The project was presented to all the executive council members, at a City Council meeting, for which a municipal investment of more than 1.2 million euros is expected" and an implementation period of no more than 360 days." 28

In order to "return the Oliveira Lopes School building to the population, without neglecting the purpose for which it was built: promote education, training for the community and the revitalisation of local economy"29, the reconstruction of the building will consider a number of new purposes, not forgetting, of course, its unique function as a museum:

- A space to support the activities of associations, which includes an office and a multipurpose rehearsal hall equipped for theatres rehearsals, dancing, music and exhibitions and workshops; a multipurpose space for plastic art installations;

- A cafeteria open to the public;

- A space dedicated to teaching, formed by a library, the Senior University/educational service, and a Creative Industries Room;

- A space dedicated to museology, with rooms for archives/document centre, workshop, museum reserves and technical offices;

- $\quad$ performance hall and auditorium;

- two exhibition rooms. ${ }^{30}$

Having well-defined objectives, the intention of the School Museum is to value the building and the collection of the Oliveira Lopes School; study, inventory, preserve and properly showcase the school collection; research the history, the memories and the representations of the school space and its collection; collect, register and analyse the immaterial heritage related to the school museum heritage, and be part of the Portuguese Museum Network. ${ }^{31}$

In the meantime, it will be closed so that a new phase in its history may begin.

\section{Conclusions}

This example has been summarised for various reasons.

First, because it portrays the typical Brazilian from the late 19th century and early decades of the 20th century who, far from being part of the illiteracy numbers wrongly attributed to our emigrants, sees in education an essential opportunity for narrowing the gap between the country and the standards of culture and civilisation, which he has already noted in the many countries that he has visited.

Second, because the pain he feels of "abandonment in search of fortune" is mitigated with the welfare of his fellow countrymen and the "reputation of his homeland". Third, because his return unquestionably introduces a new meaning and a new pace to the search for solutions to everlasting problems, whether in the

\footnotetext{
${ }^{28}$ https://www.cm-ovar.pt accessed on 6th September 2015.

${ }^{29}$ Ibidem.

${ }^{30}$ Ibidem.

31 "Proposal document for the musealisation of the Oliveira Lopes School", lent by the Board of the Oliveira Lopes School Museum.
} 
area of religion, health or education.

Finally, because even though the Brazilians belonged to the reduced 5\% who had managed to find in Brazil the fortune that allowed them to become benefactors, they used part of it at the service of their country, a country so lagging behind that it had pushed them into emigration. But they nevertheless wished to put an end to that migration flow, by investing in the only way that would make this utopia possible - to leave wealth in Portugal to create, both through the economy or instruction/education, the potential for a life that did not force anyone to resort to going overseas to be fully accomplished.

This example, however, is also quite unique.

The status of the Oliveira Lopes Schools is dear in the imagery of the local people. Modern, well-equipped, comfortable, central, set in a rural area that lacked almost all but misery and desolation, these schools played a fundamental role over more than a century for the people from this parish in the municipality of Ovar. But much more interesting than seeing its respectable long life is to see how this institution was able to reinvent itself. It is obvious that many have come together to make this possible: the Oliveira Lopes family who from the early benefactors to their descendants has never abandoned the project begun in 1908; the energetic, active and resilient Association of Former Students of the Oliveira Lopes School; Joaquim de Almeida Pinho, who taught for more than thirty years at the school for boys. Although nearly retired, he cannot accept the loss of this unique collection in Portugal.

\section{References}

Alves, J. F. (1994). Os Brasileiros - Emigração e Retorno no Porto Oitocentista. Porto: Edição de Autor.

Alves, J. F. (1992). Percursos de um brasileiro do Porto - O Conde Ferreira. In Revista da Faculdade de Letras - História, II série, vol. IX, Porto, pp. 199-213.

Bárbara, A. M. (1979). Subsídios para o Estudo da Educação em Portugal - da reforma pombalina à $1^{a}$ República. Lisboa: Assírio \& Alvim.

Campagne, E. M. (Dir.) (1873). Diccionário Universal de Educação e Ensino. Porto: Livraria Internacional de Ernesto Chardron, vol. I.

Castro, F. (1977). Emigrantes. Lisboa: Guimarães \& C. ${ }^{a}$ Editores.

Colecção Oficial de Legislação Portuguesa - Ano de 1866. Lisboa: Imprensa Nacional, 1867.

Colecção Oficial de Legislação Portuguesa - Ano de 1907. Lisboa: Imprensa Nacional, 1908.

Comissão Nacional para as Comemorações do Centenário da República. (2011). Educar: educação para todos: ensino na I República. Lisboa: Comissão Nacional para as Comemorações do Centenário da República.

Costa, D. A. (1900). História da Instrução Popular em Portugal (Desde a fundação da monarquia até aos nossos dias). Porto: Editor António Figueirinhas.

Cruz, M. A. (1986). Agruras dos Emigrantes Portugueses no Brasil - Contribuição para o estudo da emigração portuguesa na segunda metade do século XIX. In Revista de História, Porto: INIC/Centro de História da Universidade do Porto, 87, vol. VII.

Cruz, M. A. (1991). Do Porto para o Brasil: A outra face da Emigração Oitocentista à Luz da Imprensa Portuense. In Revista de História, Porto: INIC/Centro de História da Universidade do Porto, vol. XI.

Dinis, J. (1982). A Morgadinha dos Canaviais. Lisboa: Editora Ulisseia.

Dinis, J. (1991). Serões da Província. Lisboa: Publicações Europa América.

Escolas Primárias no concelho de Guimarães - 1866 a 1900. Arquivo Municipal Alfredo Pimenta - Guimarães.

Gomes, J. F. (1985). Relatórios do Conselho Superior de Instrução Pública (1844-1859). Coimbra: INIC/Centro de Psicopedagogia da Universidade de Coimbra.

Mónica, M. F. (1987). Capitalistas e Industriais (1870-1914). In Análise Social, Vol. XXIII (99).

Nóvoa, A. (1987). Letempsdesprofesseurs: Analyse socio - historique de la professionenseignante au Portugal (XVIIIe-XXesiècle). Préface de Daniel Hameline. Lisboa: INIC. 
Património Escolar - Uma cultura de sensibilidade. Revista "Educação no Centro", n. 2, Abril de 1999. Edição da Direção Regional do Centro.

Pinho, J. A. (2010). A Centenária Oliveira Lopes. A História. O Museu. Ovar: Câmara Municipal de Ovar.

Pinho, J. A. (2002). Museu Escolar Oliveira Lopes. Pequena História. Ovar: Associação de Antigos Alunos da Escola Oliveira Lopes.

Reis, J. (1993). O Analfabetismo em Portugal no século XIX: uma interpretação. In Colóquio/Educação e Sociedade, Lisboa.

Ribeiro, D. A. (1884). Noticia das Irregularidades da Execução do Testamento do Benemérito Snr. Conde de Ferreira e dos prejuízos causados por culpa ou dolo dos seus testamenteiros. Porto: Tipografia de A.J. ds Silva Teixeira.

Rocha-Trindade, M. B. (1986). Refluxos culturais da emigração portuguesa para o Brasil. In Análise Social, vol. XXII (90).

Rodrigues, A. S. (2002). Imagens da memória educativa. O Museu Escolar de Válega. In RODRIGUES, António Simões (coord.)

- Património Escoar. Escola Primária, alicerce de uma caminhada. Lisboa: Ministério da Educação.

Sá, V. (1981). Época Contemporânea Portuguesa I - Onde o Portugal Velho Acaba. Lisboa: Livros Horizonte.

Silva, M. J. S. O. (1992). As Elites Locais e sua influência nos fins do século XIX e primeiras décadas do século XX - um exemplo:

Domingos Joaquim da Silva, Visconde de Salreu (1854 - 1936). Coimbra: Edição de Autor.

Valério, N. (1998). A Imagem do Brasileiro na obra literária de Júlio Dinis. Lisboa: Gabinete de História Económica e Social. 